\title{
Influence of Some Macroeconomic Variables on Inflation-An Econometric Enquiry
}

\author{
Amit Kundu \\ Department of Economics, Mathabhanga College, Cooch Behar, India \\ Email address: \\ ms.amitkundu@rediffmail.com

\section{To cite this article:} \\ Amit Kundu. Influence of Some Macroeconomic Variables on Inflation-An Econometric Enquiry. Journal of World Economic Research. \\ Vol. 6, No. 3, 2017, pp. 27-33. doi: 10.11648/j.jwer.20170603.11
}

Received: September 1, 2016; Accepted: March 8, 2017; Published: May 17, 2017

\begin{abstract}
The study analyzed the impact of exchange rate, money supply, interest rate and government expenditure on inflation of Bangladesh by using time series data from 1976-2010 by employing Bound Testing approach. The analysis demonstrates that in the long-run, rate of change of exchange rate has negative effect on inflation. Money supply and interest rate have no significant effect on inflation, and government expenditure has a positive effect on inflation. While in the shortrun, the results indicate directional causality taking inflation as dependent variable with other macro-economic variables like exchange rate, money supply, interest rate and government expenditure. It is manifest that inflation is sensitive to changes both interest rate and government expenditure in the short run. Therefore, the government should realise effective macro-economic policies that is effective for economical progress in the short run. The policy implication is that in Bangladesh to lessen inflation momentum the government will have to pursue a monetary and fiscal policy which matches with the actual scenario of real sectors and monetary sectors.
\end{abstract}

Keywords: ARDL, Bound Testing, Error Correcting Term, Exchange Rate, Govt. Expenditure Inflation, Interest Rate, Money Supply

\section{Introduction}

The emergence of substantial inflation figure in Asia and Bangladesh in particular has led to widespread studies about its causes. Relentless price increases affect every economic unit. Every country has a responsibility of ensuring stability in general price level as one of macroeconomic objectives to achieve economic development.

Inflation is generally used to describe a situation of rapid, persisted and unacceptably high rises in the general price level in an economy, resulting to general loss of purchasing power of the currency. Inflation causes serious discomfort for consumers, investors, producers and the government (Remond, 2014, p.1). Long term inflation occurs when the money supply grows at a faster rate than the output of goods and services. This situation occurs when there is more money than is needed to accommodate nominal growth in output, consumers and businesses want to purchase more goods and services than can be produced with current resources (labor, materials, etc.) causing upward pressures on prices. Over a short term, inflation can take place from various shocks in the economy. Food and energy price shocks are common examples of this type of inflation in Bangladesh. A price of a commodity such as fuel may rise suddenly and sharply, relatively to other commodities prices response, may result to short term increase in overall prices.

Inflation in Bangladesh has become a major concern to the government. Several macroeconomic policies were introduced to control inflation in the economy and in spite of these policies, inflationary trends continue to vary. Government needs to control inflation since it can severally disrupt the economy. The tools governments normally use include monetary policy (i. e. increase or decrease in the money supply and interest rate), fiscal policy (changes in the amount of taxes and government spending) and various controls on prices, tariffs, etc. As a primary tool many nations choose monetary policy. It has proven to be effective, less troublesome to the market operations and easier and quicker to put into practice since adjusting the money supply does not require legislative approval as would be for instance changing the tax structure.

Monetary aspect, inflation is considered to be due to an 
increase in money supply, in fiscal aspect, budget deficits are the fundamental causes of inflation. However, the fiscal aspect is closely connected to monetary enlightenment of inflation since government deficits are often financed by money creation in developing countries. In the balance of payment aspect, emphasis is placed on exchange rate. That is the collapse of exchange rate brings about inflation either through higher import prices and increase in inflationary expectation, which are often accommodated or through an accelerated wage indexation mechanism (Akinbobola, 2012)

However, the problems of inflation and its effects continued unabated. Studies reveal growth in money supply, government deficit financing and exchange rate decreased agricultural and industrial production among other were responsible for inflationary pressure in Bangladesh. And the most significant effect of inflation is its impact on government revenues and non-performance of the economy. Inflation also makes budgeting and future planning difficult for economic agents imposes a drag on productivity, particularly when firms are forced to shift resources away from products and services, thereby discouraging investment and retarding growth (Orubu, 2009).

Milton Friedman (1963) wrote Inflation is always and everywhere a monetary phenomenon. The Quantity Theory of Money leads us to agree that the growth in the quantity of money is the primary determinant of the inflation rate. John Maynard Keynes (1936) argued that demand determines output, which, in turn, determines employment and prices. At full employment of men and capital, excessive demand for goods and services drives up the general level of prices causing inflation. The biggest challenge in macro-economic management is reining the inflation. The inflation rate of Bangladesh in the last five years, starting from FY 2004-05 is above 6 percent and in 2010 is 8.44 percent, with the nonfood inflation close to 5.37 percent and food inflation 10.34 percent. The gap between the targeted GDP growth rate and the achieved GDP growth in the last twenty years revealed that increase in average inflation may be one of the major reasons (Bangladesh Economic Update, 2010).

The high inflation rate has become a serious concern in the industrial and emerging market economies globally. Inflation constitutes one of the factors responsible for poverty, low standard of living and growth in Bangladesh. Hence, the paper is to investigate into the root causes of inflation in Bangladesh.

\section{Theoretical Issues and Literature Review}

Inflationary discourse still remains the most contentious Macroeconomic studies which have theoretical basis in the perspective of both the Monetarist and the Keynesian schools of thought. Most economist before Keynes had underscored the relationship between the amount of money supply and the level of general prices, however, with varying degree of emphasis. The quantity theory of money states that the general price level changes in direct proportion to a change in the level of money supply.

Keynes (1936) posited that inflation is caused by a situation of excess aggregate demand over aggregate supply when there is no excess capacity, a situation in which the economy operates at full employment of resources. Furthermore, there are strong arguments that fiscal deficits are a major cause of inflation. Abolo (1997) among other researchers also supported it.

The argument that price inflation is significantly determined by the process mark-up on the costs of firm's production process has been advanced in the models of Goacher (1986) and Gordon (1984) believed that inflation could result from the cost of imported goods rising independently of the demand for them in the domestic economy.

Most recently, there is an emerging trends of literature on inflation came to be known as the political economy approach to macroeconomic policy (Selialia, 1995). These recent theories of inflation have shifted attention away from traditional direct economic causes of inflation, such as money creation, towards political and institutional determinants of inflationary pressures because being theoretical and put emphasis almost exclusively on industrial countries.

There is a relatively large literature dealing with relations between monetary indicators and other macroeconomic variables. Doroshenko, (2001), consider the relation between both money supply and inflation and between money supply and inflation and found a long-run relationship between money growth and inflation. Clemens and Alex (2002) empirically estimated the relationship between exchange rate accommodation and the degree of inflation persistence using a non-linear autoregressive inflation equation for ten European countries for the period 1974-1998. Their results provide supportive evidence for the existence of a positive link between exchange rate accommodation and inflation persistence for most of the smaller and more dependent exchange rate mechanism countries, even when mean level shift in inflation are appropriately accounted for.

Mahamadu and Philip (2003) explore the relationship between monetary growth, exchange rate, and inflation in Ghana using Error Correction Mechanism The result confirms the existence of a long run equilibrium relationship between inflation, money supply, exchange rate and real income. In line with theory, the finding demonstrates that in the long run, inflation in Ghana is positively related to the money supply and exchange rate and negatively related to real income.

Odusanya and Atanda (2010) analyzed the dynamics and simultaneous inter-relationship between inflation and its determinants in Nigeria between 1970 and 2007 examined using the Augmented Dickey Fuller (ADF) and unit root test. The result reveals that inflation rate, growth rate of real output, money supply and real share of fiscal deficit are stationary at levels, while, other incorporated variables-real share of import, exchange rate and interest rate are stationary 
at first difference. Adeyeye and Kola also examined the causes and effects of inflation in Nigeria between 1969 and 2009 and what could be done to ameliorate the negative effects on the economy. The time series variables properties on some selected variables were examined using ADF unit root test and co- integration analysis. The result reveals that money supply, growth rates, gross domestic product growth rate and expenditure revenue ratio are not spurious but exchange rate of dollar to Naira was non-stationary. The study also reveals that the GDP growth rate is counter inflationary as against inflationary factors. It is sufficed to say that causes of inflation is one of the most highly treated subject in economic researches and literature (Aminu, 2014, p.140/141). Taslim (1980) used regression models for explaining the inflationary process of Bangladesh. He explored that one year lagged money supply had significant positive effect on inflation.

\section{Estimation of the Models}

Augmented Dickey-Fuller (ADF) unit root test was applied in checking the order of integration of the series. The results of the estimates are reported in Table 1.

Table 1. Results Of Augmented Dickey-Fuller Tests for Unit Root of variables concerned.

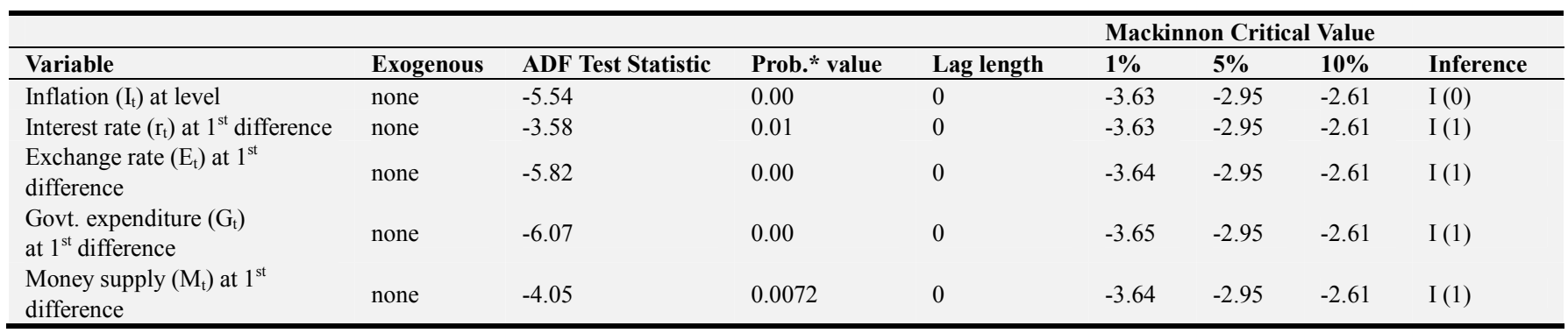

It is important to note that the combination of both I (0) and I (1) variables would not be possible under the Johansen system. This therefore, provides a good justification for using the bounds test approach, or ARDL model, proposed by Pesaran et al (2001).

\section{Methodology}

The ARDL model can be specified as follows: give

$$
I_{t}=\alpha_{0}+\alpha_{1} E_{t}+\alpha_{2} M_{t}+\alpha_{3} R_{t}+\alpha_{4} G_{t}+\varepsilon_{t}
$$

Where $I$ is Inflation, $E$ is exchange rate, $M$ is money supply, $R$ is interest rate and $G$ is govt. expenditure. $\varepsilon$ is a white noise process and $t$ is the time period. The equation (1) is my model and from this model the ARDL model can be specified.

\section{Estimation Techniques}

The methodology used in this study is based on the autoregressive distributed lag (ARDL) model which does not involve pre-testing variables. This methodology is used to examine the cointegration relationship among $I_{t}, E_{t}, M_{t}, R_{t}$ and $G_{t}$ variables.

ARDL framework for the above equation is given as

$$
\begin{gathered}
\Delta I_{t}=\alpha_{0}+\sum_{i=1}^{n} \alpha_{1 i} \Delta I_{t-1}+\sum_{i=1}^{n} \alpha_{2 i} \Delta E_{t-1}+\sum_{i=1}^{n} \alpha_{3 i} \Delta M_{t-1}+\sum_{i=1}^{n} \alpha_{4 i} \Delta R_{t-1}+\sum_{i=1}^{n} \alpha_{5 i} \Delta G_{t-1}+\beta_{1} I_{t-1}+\beta_{2} E_{t-1}+ \\
\beta_{3} M_{t-1}+\beta_{4} R_{t-1}+\beta_{5} G_{t-1}+\varepsilon_{t}
\end{gathered}
$$

The ARDL model testing method starts with conducting the bound test, which states the null hypothesis of zero cointegration, i. e.

$$
H_{0}=\beta_{1}=\beta_{2}=\beta_{3}=\beta_{4}=\beta_{5}=0
$$

Against the alternative hypothesis of the existence of cointegration, i. e.

$$
H_{0} \neq \beta_{1} \neq \beta_{2} \neq \beta_{3} \neq \beta_{4} \neq \beta_{5} \neq 0
$$

The statistic underlying the procedure is the F-statistic which is used to test the significance of lagged levels of the variables, in order to establish the existence of cointegration. Two sets of critical values are reported in Pesaran and Pesaran (1997), Pesaran et al (2001) or Narayan (2004). The critical values are divided into upper and lower critical bounds. The upper critical values assume that all the series are I (1) while the lower critical values assume that all the series are I (0). In the bound testing approach, the calculated F-statistic is compared with the critical values provided by Pesaran and Pesaran (1997), Pesaran et al (2001) or Narayan (2004). However, due to the limited number of sample observations, the critical values in this paper are extracted from Narayan (2004). If the computed F-statistic falls outside the critical bound, a conclusive inference can be made without considering the order of integration of the underlying regressors. For instance, if the F-statistic is higher than the upper critical bound, then the null hypothesis of no cointegration is rejected. Alternatively, if the F-statistics is lower than the lower critical bound, then the null hypothesis of nocointegration cannot be rejected. If however the calculated F-statistic lies within the lower and upper bounds, then the test is said to be inconclusive. In this context, the unit root tests should be conducted to ascertain the order of integration of the variables. If all the variables are found to 
be I (1), then the decision is taken on the basis of the upper critical value. On the other hand, if all the variables are I (0), then the decision is based on the lower critical bound value.

Once cointegrating relationship is determined, the error correction estimates of the ARDL model are obtained. The diagnostic test statistics of the selected ARDL model can be checked from the short run estimates at this stage of the estimation method. Similarly, the test for parameter stability of the model can be executed. The error correction representation of equation (2) can be precised as follows:

$$
\begin{gathered}
\Delta I_{t}=\alpha_{0}+\sum_{i=1}^{n} \alpha_{1 i} \Delta I_{t-1}+\sum_{i=1}^{n} \alpha_{2 i} \Delta E_{t-1}+\sum_{i=1}^{n} \alpha_{3 i} \Delta M_{t-1} \\
+\sum_{i=1}^{n} \alpha_{4 i} \Delta R_{t-1}+\sum_{i=1}^{n} \alpha_{5 i} \Delta G_{t-1} \\
+\gamma E C T_{t-1}+\varepsilon_{t}
\end{gathered}
$$

Where ECM is the error correction term which measures the speed of adjustment, and $\gamma$ is the coefficient of the error correction term, which is expected to be negative and statistically significant to further confirm the existence of a cointegrating association.

\section{Sources of Data}

The time series data were derived from various secondary sources such as: Indian Financial Statistics. The macroeconomic data covers between 1976- 2010. Base period is 2000. Log of variables has been used in my research work. The data gathered were subjected to various econometric tests with the aid of E-views.

\section{Empirical Analysis}

\subsection{Bound Test Cointegration Results}

In order to perform the bound testing procedure, equation (2) using the ARDL approach to cointegration, to examine the long run relationships among the variables in equation (1). A lag length of 2 was chosen as the maximum lag length based on the AIC and SIC. This is also consistent with Pesaran and Shin (1999) who recommended choosing a maximum lag length of 2 for small sample annual data. The F-statistic and critical bounds values for testing the null of no cointegrating relationship are reported in table- 2 .

Table 2. Bounds Test for Cointegration Analysis.

\begin{tabular}{lll}
\hline Critical value & Lower Bound Value & Upper Bound Value \\
\hline $1 \%$ & 3.74 & 5.06 \\
$5 \%$ & 2.86 & 4.01 \\
$10 \%$ & 2.45 & 3.52 \\
\hline
\end{tabular}

Note: Computed F-statistic: 6.47 (Significant at 0.05 marginal values). Critical Values are cited from Pesaran et al. (2001), Table CI (iii), Case 111: Unrestricted intercept and no trend.

Table 3. Bounds Test Results.

\begin{tabular}{llll}
\hline Variables & F-Statistic & Probability & Inference \\
\hline It, Et $, \mathrm{Mt}, \mathrm{Rt}, \mathrm{Gt}$ & 6.47 & 0.0018 & Cointegration \\
\hline
\end{tabular}

The estimated coefficients of the long-run relationship between It, Et, Mt Rt, Gt are expected to be significant.

Table 4. Long-run estimated coefficients based on equation (2).

\begin{tabular}{lllll}
\hline Variables & Coefficient & Standard Error & T-Ratio & Probability \\
\hline Constant & 5.91 & 2.73 & 2.16 & 0.03 \\
Et, & -8.49 & 2.49 & -3.40 & 0.001 \\
Mt & 0.88 & 0.67 & 1.30 & 0.20 \\
Rt & 0.90 & 0.70 & 1.28 & 0.20 \\
Gt & 2.24 & 0.85 & 2.61 & 0.01 \\
R2 $=0.30$, Adjusted R2 $=0.20$, Log likely hood=-13, F-Stat $=3.13$, AIC-1.07, \\
SIC $=1.29$
\end{tabular}

Dependent variable: d (log Inflation)

The calculated F-statistic when inflation is the dependent variable is 6.47 , which is higher than the upper bound critical value at the $5 \%$ level of significance (4.01). This implies that the null hypothesis of no cointegration is rejected at the $5 \%$ level and that there is indeed a cointegration relationship among the inflation and its determinants.

\subsection{Long Run and Short Run Dynamics}

There is a long run association as far as bound test is concerned. Results are given in table -5 . The results suggest that exchange rate has negative effect on inflation, money supply and interest rate have no significant effect on inflation, and government expenditure has positive effect on inflation.

Table 5. Error Correction Representation for the Selected ARDL Model.

\begin{tabular}{lllll}
\hline Dependent Variable: D (INFLATION) & & & & \\
\hline Variable & Coefficient & Std. Error & t-Statistic & Prob. \\
\hline C & -0.016047 & 0.253381 & -0.063333 & 0.9501 \\
D (INFLATION (-1)) & 0.805913 & 0.387620 & 2.079129 & 0.0507 \\
D (INFLATION (-2)) & 0.360397 & 0.274169 & 1.314506 & 0.2036 \\
D (EXCHANGERATE (-1)) & 7.030518 & 4.166130 & 1.687542 & 0.1070 \\
D (EXCHANGERATE (-2)) & 1.571135 & 3.728362 & 0.421401 & 0.6780 \\
D (MONEYSUPPLY (-1)) & 0.038490 & 2.538937 & 0.015160 & 0.9881 \\
D (MONEYSUPPLY (-2)) & 1.714355 & 2.706644 & 0.633388 & 0.5337 \\
D (INTERESTRATE (-1)) & -3.793734 & 1.997255 & -1.899474 & 0.0720 \\
D (INTERESTRATE (-2)) & 3.327917 & 1.712781 & 1.942990 & 0.0662 \\
D (GOVTEXPENDITURE (-1)) & -6.579168 & 2.170203 & -3.031591 & 0.0066 \\
\hline
\end{tabular}




\begin{tabular}{|c|c|c|c|c|}
\hline \multicolumn{5}{|c|}{ Dependent Variable: D (INFLATION) } \\
\hline Variable & Coefficient & Std. Error & t-Statistic & Prob. \\
\hline D (GOVTEXPENDITURE (-2)) & 1.420193 & 1.370513 & 1.036249 & 0.3125 \\
\hline ECT (-1) & -1.962548 & 0.494318 & -3.970214 & 0.0008 \\
\hline R-squared & 0.774936 & \multicolumn{2}{|c|}{ Mean dependent var } & 0.007590 \\
\hline Adjusted R-squared & 0.651151 & \multicolumn{2}{|c|}{ S. D. dependent var } & 0.633897 \\
\hline S. E. of regression & 0.374401 & \multicolumn{2}{|c|}{ Akaike info criterion } & 1.153018 \\
\hline Sum squared resid & 2.803524 & \multicolumn{2}{|c|}{ Schwarz criterion } & 1.702669 \\
\hline Log likelihood & -6.448292 & \multicolumn{2}{|c|}{ Hannan-Quinn criter. } & 1.335212 \\
\hline F-statistic & 6.260340 & \multicolumn{2}{|c|}{ Durbin-Watson stat } & 1.811603 \\
\hline Prob (F-statistic) & 0.000211 & & & \\
\hline
\end{tabular}

In the above model D (INFLATION (-1)), D (INFLATION (2)), D (EXCHANGERATE (-1)), D (EXCHANGERATE (-2)), D (MONEYSUPPLY (-1)), D (MONEYSUPPLY (-2)), D (INTERESTRATE (-1)), D (INTERESTRATE (-2)), D (GOVTEXPENDITURE (-1)), D (GOVTEXPENDITURE (-2)) all are short run coefficient. ECT (-1) is the speed of adjustment parameter. It should be negative and significant. Negative and significant value of speed of adjustment parameter means that the whole system would get back long run equilibrium.

The above model should check whether the model has serial correlation or not and whether the model is stable or not.

Table 6. Serial correlation LM test.

\begin{tabular}{lcll}
\hline Breusch-Godfrey Serial Correlation LM Test: & \\
\hline F-statistic & 0.992140 & Prob. F $(2,18)$ & 0.3902 \\
Obs*R-squared & 3.177345 & Prob. Chi-Square (2) & 0.2042 \\
\hline
\end{tabular}

It is clear from the above table on the basis of F-statistic that the null hypothesis is accepted i.e., there is no serial correlation.

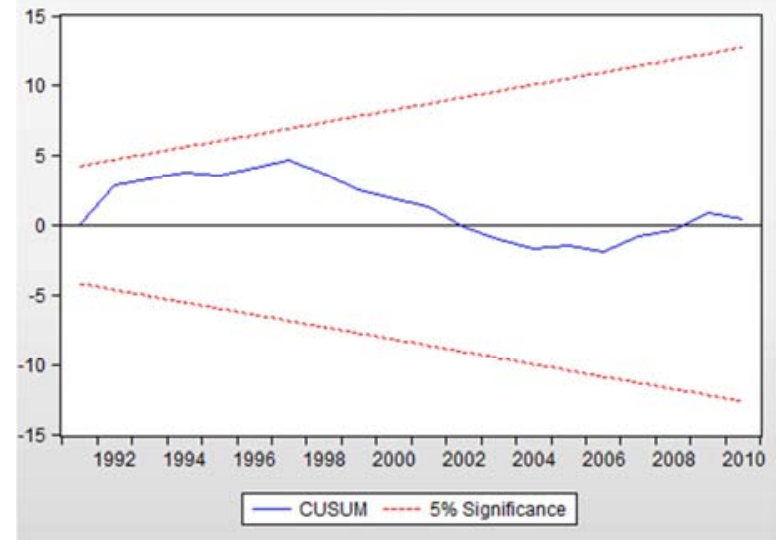

Figure 1. CUSUM Test for stability of parameters.

The diagnostic test statistics indicates that there is no evidence of serial autocorrelation in the disturbances. The coefficient of determination $\left(\mathrm{R}^{2}\right)$ indicates that the model is reasonably accurate in prediction, and 77 percent of variation in the dependent variable is accounted for by the independent variables. The stability of the regression coefficients are evaluated using cumulative sum (CUSUM) test. The regression equation appears to be stable as the CUSUM test statistics lies within the $5 \%$ critical bound as shown in the figure 1.

Short-run Causality Test (Wald Test F-statistic):

Table 7. Short run causality between inflation and exchange rate.

\begin{tabular}{llll}
\hline Wald Test: & & & \\
\hline Test Statistic & Value & df & Probability \\
F-statistic & 1.598022 & $(2,20)$ & 0.2271 \\
Chi-square & 3.196043 & 2 & 0.2023 \\
\hline
\end{tabular}

Exchange rate at lag 1 and exchange rate at lag 2 cannot jointly cause inflation because null hypothesis i. e., c $(4)=c$ (5) $=0$ is accepted. Therefore, there is no short run causality running form exchange rate to inflation.

Table 8. Short run causality between inflation and money supply.

\begin{tabular}{llll}
\hline Wald Test: & & & \\
\hline Test Statistic & Value & df & Probability \\
F-statistic & 0.216421 & $(2,20)$ & 0.8073 \\
Chi-square & 0.432843 & 2 & 0.8054 \\
\hline
\end{tabular}

Money supply at lag 1 and money supply at lag 2 cannot jointly cause inflation because null hypothesis i. e., c $(6)=\mathrm{c}$ (7) $=0$ is accepted. Therefore, there is no short run causality running form money supply to inflation.

Table 9. Short run causality between inflation and interest rate.

\begin{tabular}{llll}
\hline Wald Test: & & & \\
\hline Equation: Untitled & & & \\
\hline Test Statistic & Value & df & Probability \\
\hline F-statistic & 2.472744 & $(2,20)$ & 0.1097 \\
Chi-square & 4.945488 & 2 & 0.0844 \\
\hline
\end{tabular}

Interest rate at lag 1 and interest rate at lag 2 can jointly cause inflation because null hypothesis i. e., c $(8)=\mathrm{c}(9)=0$ is rejected. Therefore, there is a short run causality running form interest rate to inflation.

Table 10. Short run causality between inflation and govt. expenditure.

\begin{tabular}{llll}
\hline Wald Test: & & & \\
\hline Equation: Untitled & & & \\
\hline Test Statistic & Value & df & Probability \\
\hline F-statistic & 5.941915 & $(2,20)$ & 0.0094 \\
Chi-square & 11.88383 & 2 & 0.0026 \\
\hline
\end{tabular}

Govt. expenditure at lag 1 and govt. expenditure at lag 2 can jointly cause inflation because null hypothesis i. e., c $(10)=c(11)=0$ is rejected. Therefore, there is a short run causality running form govt. expenditure to inflation. 


\section{Conclusion \& Policy Implication}

This paper has estimated the impact of exchange rate, money supply, interest rate and government expenditure on inflation of Bangladesh by using time series data from 19762010 by employing Bound Testing approach. The analysis demonstrates that in the long-run, exchange rate has negative effect on inflation, money supply and interest rate have no significant effect on inflation, and government expenditure has positive effect on inflation.

While in the short-run, the results indicate directional causality taking inflation as dependent variable and exchange rate, money supply, interest rate and government expenditure.
It is manifest that inflation is sensitive to changes both interest rate and government expenditure. Therefore, the government should realise effective macro-economic policies. The policy implication is that in Bangladesh to lessen inflation momentum the government will have to pursue a monetary and fiscal policy which matches with the actual scenario of real sectors and monetary sectors. Govt. spending should be prudently utilized.

There is a recommendation that further study should be carried out using different sets of variables with appropriate mathematical models to detect determinants of the inflation in Bangladesh.

\section{Appendix}

Table 11. Estimated Model based on equation (2).

\begin{tabular}{|c|c|c|c|c|}
\hline \multicolumn{5}{|c|}{ Dependent variable: $1^{\text {st }}$ difference inflation (D Inflation) } \\
\hline Variable & Coefficient & Std. Error & t-Statistic & Prob. \\
\hline $\mathrm{C}$ & -1.077 & 5.821 & -0.185 & 0.85 \\
\hline D (INFLATION (-1)) & 0.309 & 0.427 & 0.725 & 0.47 \\
\hline D (INFLATION (-2)) & 0.279 & 0.270 & 1.032 & 0.31 \\
\hline D (EXCHANGERATE (-1)) & -8.980 & 6.636 & -1.353 & 0.19 \\
\hline D (EXCHANGERATE (-2)) & -7.575 & 4.930 & -1.536 & 0.14 \\
\hline D (MONEYSUPPLY (-1)) & 3.445 & 3.554 & 0.969 & 0.34 \\
\hline D (MONEYSUPPLY (-2)) & 4.165 & 3.236 & 1.286 & 0.21 \\
\hline D (INTERESTRATE (-1)) & -1.953 & 2.087 & -0.935 & 0.36 \\
\hline D (INTERESTRATE (-2)) & 4.800 & 1.772 & 2.708 & 0.01 \\
\hline D (GOVTEXPENDITURE (-1)) & -3.534 & 2.375 & -1.488 & 0.15 \\
\hline D (GOVTEXPENDITURE (-2)) & 2.226 & 1.285 & 1.731 & 0.10 \\
\hline INFLATION (-1) & -1.100 & 0.577 & -1.904 & 0.07 \\
\hline EXCHANGERATE (-1) & 8.983 & 9.880 & 0.909 & 0.37 \\
\hline MONEYSUPPLY (-1) & -1.813 & 1.782 & -1.017 & 0.32 \\
\hline GOVTEXPENDITURE (-1) & -1.823 & 2.349 & -0.776 & 0.44 \\
\hline \multicolumn{5}{|c|}{$\mathrm{R}^{2}=0.86$, Adjusted $\mathrm{R}^{2}=0.74, \log$ likelyhood $=1.94, \mathrm{~F}-\mathrm{Stat}=6.94, \mathrm{AIC}=0.87, \mathrm{SIC}=1.61, \mathrm{D} . \mathrm{W} .=2.47$} \\
\hline
\end{tabular}

\section{References}

[1] Adeyeye, E. A. and T. O. Fakiyesi (980) Productivity price and incomes Board and Anti inflationary policy in Nigeria in the Nigerian economy under the military. Proceedings of the 1980, Annual Conference of Nigerian Economic Society, Ibadan.

[2] Adeyeye and Kola (2012) "Empirical Analysis of the causes and effects of Inflation in Nigeria" Journal of Economic and Sustainable Development, www.iiste.org, vol.3, no.11. Pp35-40.

[3] Akibobola, T. O (2012)"The dynamics of money supply, exchange rate and inflation in Nigeria" Journal of Finance and banking, vol.2 no.4, pp117-141.

[4] Asogu, J. O. (1991)"An econometric Analysis of the nature and causes of Inflation in Nigeria" Economic and Financial Review, Vol.29, no.2.

[5] Aris, M. J. (1992) "Wage inflation" in current issues on Macroeconomics, London, Macmillan Education ltd.

[6] Batini, N. (2004) Achieving and Maintaining Price Stability in Nigeria, IM working paper, 04-97, Washington DC.

[7] Edwaikhide et al (1994) "Exchange rate, Money supply and
Inflation in Nigeria: An Empirical Investigation" African Journal of Economic Policy, vol.2Pp57-73.

[8] Eihner, A. S. (1973) "A theory of the determination of markup under oligopoly” Economic Journal, December 1973.

[9] Friedman, Milton (1963) Inflation: Causes and Consequences. New York: Asia Publishing House.

[10] Fuller, T. M. and Ikhide, (1998)'An Economic Analysis of Nigerian Consumer Price Index" Journal of Economics, vol.24 (2), Pp1-15.

[11] Goaecher, D. J. (1986) An introduction to Monetary Economic, London Financial Training Publication ltd.

[12] International Monetary Fund, 2007, Bangladesh: Selected Issues (IMF Country Report No. 07/230, June 2007), pp. 16-23.

[13] Jhingan, M. L. (2004) Monetary Economics, $6^{\text {th }}$ ed. Vrinda Publications Ltd.

[14] Keynes, J. M. (1936) The General Theory of Employment, Interest and Money. Published for the Royal Economic Society by Macmillian Press ltd, London andBasingstoke.

[15] Mahamadu, B. and Philip, A. (2003) Monetary Growth, Exchange rates and Inflation in Ghana: An Error Correction Analysis, Working Paper, WO/BOG- 2003/05. 
[16] Odusunya, I. A. and A. A. Atanda (2010): Analysis of inflation and its determinants in Nigeria, Pakistan Journal of Social Sciences, volume7, No.2 Pp97-100.

[17] Okpara and Nwoaha (2010) "Government Expenditure, Money supply, Prices and output Relationship in Nigeria: An Econometric Analysis" International Research Journal of Finance and Economic Issues54.

[18] Oruba, C. O. (2009) Inflation in Nigeria: Concept, Measurement and Control, Bullion,

[19] Central Bank of Nigeria, Vol.33 (1)

[20] Osakwe, J. O. (1983) Government Expenditure, Money supply and prices, 1970-1980, CBN Economic and Financial Review, vol.21, no.2.

[21] Oyejide, T. A. (1972) "Deficit Financing, Inflation and capital Formation: The analysiso the Nigerian economy, 1957-1970" NJESS, vol.14.

[22] Owoye, O. (2007) Money Targeting, Money Demand and
Real GDP growth in Nigeria: Do rule Apply? Journal of Business and Public Affairs Vol.1 (2) Pp1-20.

[23] Pesaran, M. H., Y. Shin. \& Smith R. (2001) "Bounds testing approaches to the analysis of level relationships", Journal of Applied Econometrics, Vol. 16:289-326.

[24] Selialia, F. L. (1995) The Dynamics of Inflation in Lesotho, Unpublished M. A Thesis, University of College Dublin.

[25] Taiwo, J. K. (2011) Econometric Analysis of the causes and effects of Inflation, MSc Thesis, Department of Mathematics, University of Abuja, Nigeria.

[26] Taiwo, J. K. and Adeyeye (2012) "Empirical analysis of the effects and causes of Inflation in Nigeria" Journal of Economics and Sustainable Development, vol.3, no.11, www.iiste.org.

[27] Taslim, M. A., 1980, 'Inflation in Bangladesh: A Reexamination of the Structuralist Monetarist Controversy'. The Bangladesh Development Studies, X (1), 100-116. 